\title{
SIMULASI DESAIN DAN ANALISIS ALAT PENDETEKSI SUHU MENGGUNAKAN PROTEUS
}

\author{
${ }^{1}$ Ahmad Charis Elyasa Hafidianto, Ardi Nugraha, Muhammad Naufal Adani \\ ${ }^{1}$ Fakultas Sains dan Teknologi, Universitas Raharja \\ Email: ${ }^{1}$ ahmad.charis@,raharja.info
}

DOI: https://doi.org/10.46880/jmika.Vol4No1.pp27-31

\begin{abstract}
ABSTRAK
Pengukuran suhu ruangan berdasarkan suhu yang ada pada ruang kelas atau ruang lainya di beberapa tempat memiliki kendala dalam beberapa kasus. Alat yang digunakan untuk mengukur suhu seperti termometer mengalami kerusakan seperti termometer tidak berfungsi kembali, terutama pada cairan di dalam termometer tersebut. Dalam menangani masalah tersebut, kami dalam membuat alat ini melakukan beberapa tahap observasi, analisis, perancangan dan desain dengan menggunakan proteus yang disarankan oleh dosen kami. Keberadaan alat kami memiliki tujuan untuk menciptakan pengukuran suhu ruangan yang lebih akurat dan efektif, dalam prosesnya tidak memerlukan waktu lama untuk memuat dan mendeteksi suhu sekitar.
\end{abstract}

Kata Kunci: Arduino Uno, Mikrokontroler, Pengukur Suhu

\section{PENDAHULUAN}

Dalam kehidupan sehari-hari tentu setiap orang memerlukan jaringan elektronika untuk menunjang segala kegiatan yang akan dilakukan. Seiring dengan munculnya berbagai inovasi yang tiada hentinya. Perlu juga diperhatikan bahwa penggunaan komponen elektronika secara luas sudah mencakup ke segala bidang kehidupan manusia yang semakin canggih .Salah satu komponen elektronika yang paling sering kita dengar yaitu sensor suhu. Suhu merupakan salah satu hal yang dapat menjelaskan mengenai kondisi lingkungan. Misalnya pencatatan statistik suhu dari sebuah kota, gunung, ruangan, ruang pembakaran pada pembangkit listrik tenaga gas, dan lain-lain pasti akan lebih mudah tanpa harus mencatat secara manual dengan waktu tertentu (Malvino, 2000). Kebutuhan akan data mengenai kondisi lingkungan sekitar telah mendorong kami untuk membuat alat yang bisa mengetahui kondisi lingkungan. Pengambilan data berupa suhu suatu lingkungan sangat dibutuhkan, misalnya untuk mengetahui kondisi suhu pada ruang komputer Server yang harus terjaga suhunya. Pengukuran suhu juga sangat dibutuhkan dalam suatu penelitian atau pengamatan pada suatu lingkungan. Hal tersebut akan merepotkan dilakukan jika data tersebut dibutuhkan secara berkala untuk pengamatan suatu lingkungan.

Oleh karena itu dibutuhkan suatu perangkat yang dapat mengukur suhu tersebut. Untuk itu dibuatkanlah alat atau tools untuk membantu mendesain rangkaian atau $\mathrm{PCB}$ yang kita gunakan bernama proteus. Dan adapun alat untuk mendesain dengan sebuah gambar atau schema bisa digunakan alat yang bernama fritzing.

Proteus sangat membantu untuk mendesain sebuah rangkaian PCB untuk dibuatkan nantinya sebuah implementasi alat yang nantinya tidak terjadi kesalahan dalam prosesnya. Namun ada beberapa kendala dalam menggunakan alat ini, yaitu. Tidak lengkapnya library dari sebuah komponen yang disediakan oleh aplikasi ini sehingga menjadi sedikit faktor penghalang dalam pembuatan desain sensor suhu ini.

\section{METODE PENELITIAN}

Penelitian yang dilakukan merupakan penelitian dan pengembangan (Research and Development). Metode penelitian dan pengembangan (R\&D) merupakan metode penelitian yang digunakan untuk menghasilkan rancangan terhadap produk baru, menguji keefektifan produk yang telah ada, serta mengembangkan dan menciptakan produk baru. Berdasarkan buku Richey and Klein (2009) terdapat tiga langkah penelitian dan pengembangan, yaitu dimulai dari tahap perencanaan (planning), kemudian proses produksi (production) dan yang terakhir adalah tahap evaluasi (evaluation).

Tahap perencanaan, dimulai dengan melakukan analisis kebutuhan melalui studi literatur ataupun mengumpulkan informasi yang berkaitan dengan penelitian untuk dilakukan ke tahap perancangan. Kemudian pada tahap produksi, dilakukan pembuatan produk sesuai dengan rancangan yang sudah dibuat. Adapun produk yang dirancang dalam penelitian ini 
adalah alat sensor suhu dengan menggunakan Arduino Uno.

Setelah selesai pada tahap produksi maka tahap terakhir yang akan dilakukan adalah tahap evaluasi, pada tahap evaluasi ini dilakukan kegiatan berupa pengujian produk, untuk menilai apakah produk yang telah dirancang dan dibuat bekerja baik sesuai dengan tujuan awal yang telah ditentukan.

Dalam penelitian ini tahapan evaluasi dilakukan dengan cara pengujian produk secara keseluruhan. Untuk sensor suhu TMP36 ini akan dibandingkan dengan termometer ruangan biasa yang menggunakan alkohol. Nantinya akan didapatkan perbedaan kecepatan pembacaan suhu antara keduanya.

Dalam Gambar 1. Diagram blok diperlihatkan bahwa sensor suhu TMP36 membaca suhu dalam ruangan yang kemudian suhu yang terbaca menjadi tegangan dan kemudian diterjemahkan oleh arduino UNO lalu kemudian suhu ditampilkan pada LCD 16x2 sebagai penerima.

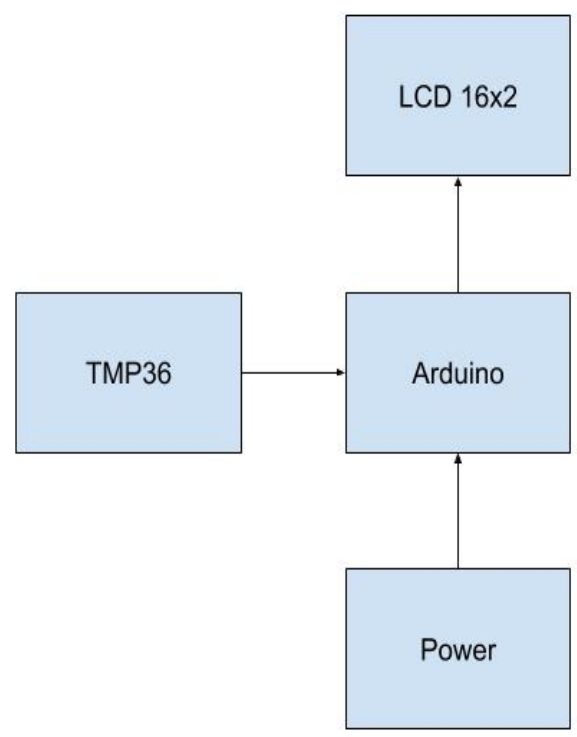

Gambar 1. Diagram Blok Sensor Suhu

\section{Desain Alat}

Desain dari Arduino Uno berbasis ATmega328 memiliki 14 pin input dari output digital dimana 6 pin input tersebut dapat digunakan sebagai output PWM dan 6 pin input analog, $16 \mathrm{MHz}$ osilator kristal, koneksi USB, jack power, dan ICSP header. Tampilan dari Desain board mikrokontroler dapat dilihat pada Gambar berikut ini.

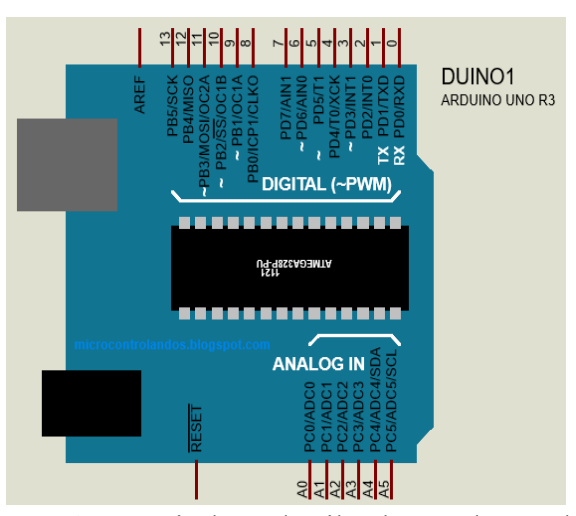

Gambar 2. Desain board mikrokontroler Arduino UNO berbasis ATmega328

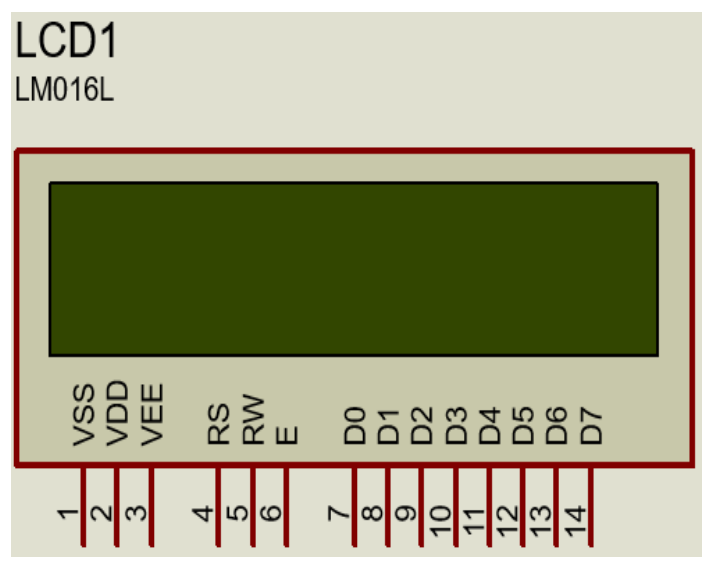

Gambar 3. LCD memiliki beberapa pin yang diantaranya digunakan untuk mengirim data untuk menampilkan tulisan keluaran yang diperintah oleh Arduino

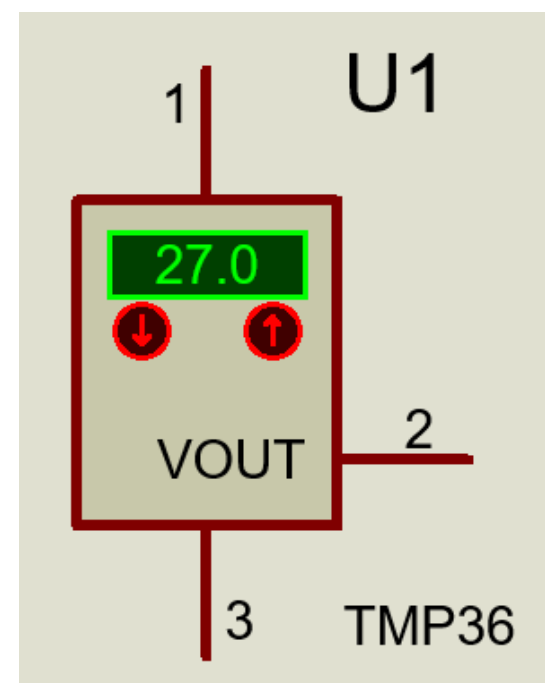

Gambar 4. Desain TMP36 adalah sensor yang bisa digunakan untuk mengukur suhu. Memiliki 3 pin. PIN

(1) menuju ke power, PIN (2) adalah pin yang digunakan untuk mengirim data ke arduino, dan PIN (3) menuju ground. 


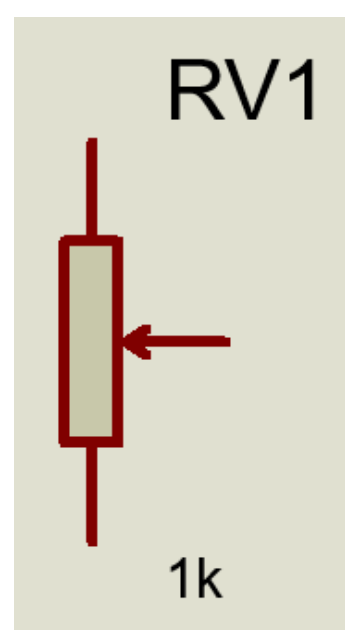

Gambar 5. Desain Potentiometer memiliki 3 Pin yang mana pada projek kami bisa digunakan untuk mengatur kecerahan pada layar LCD

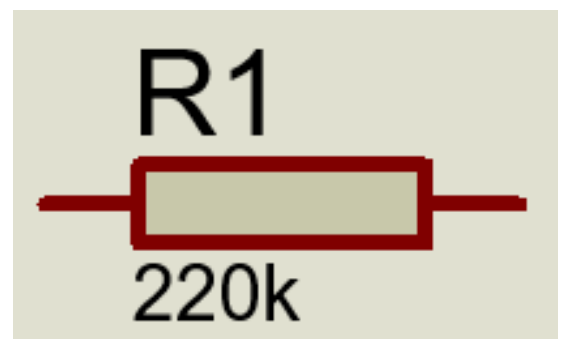

Gambar 6. Desain Resistor 220k $\Omega$

\section{Perbandingan alat sensor suhu yang kami buat dengan termometer biasa}

Kelebihan alat sensor suhu menggunankan mikrokontroler arduino dibandingkan dengan thermometer konvensional ditampilkan pada Tabel 1 berikut:

Tabel 1. Perbandingan Kelebihan

\begin{tabular}{|c|c|}
\hline $\begin{array}{c}\text { Kelebihan Alat Sensor } \\
\text { Suhu Menggunakan } \\
\text { Mikrokontroller } \\
\text { Arduino }\end{array}$ & $\begin{array}{c}\text { Kelebihan Thermometer } \\
\text { Konvensional } \\
\text { (Air Raksa) }\end{array}$ \\
\hline 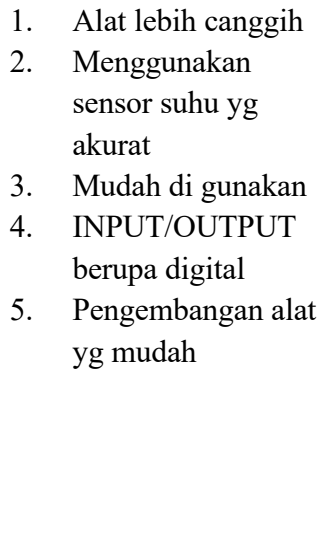 & 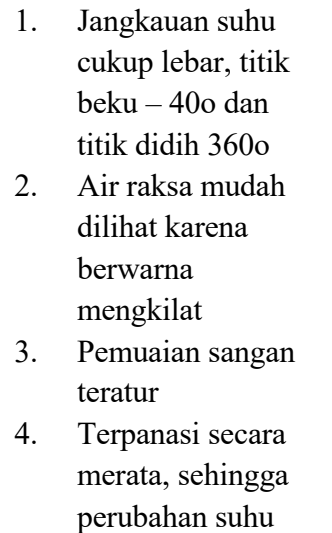 \\
\hline
\end{tabular}

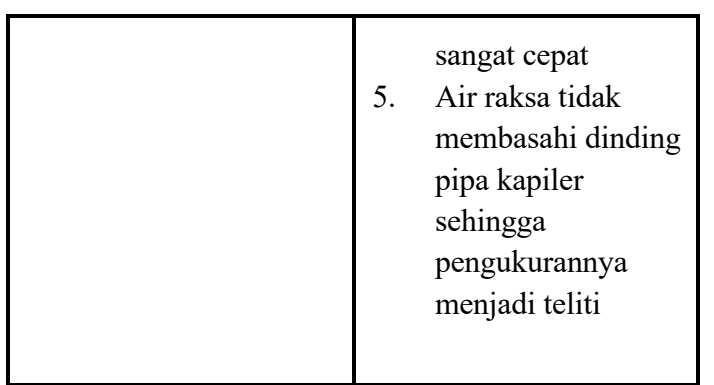

Sedangkan perbandingan kekurangan alat sensor suhu menggunakan mikrokontroler arduino dibandingan dengan thermometer konvensional ditampilkan pada Tabel 2 berikut.

Tabel 2. Perbandingan Kekurangan

\begin{tabular}{|c|c|}
\hline $\begin{array}{c}\text { Kekurangan Alat Sensor } \\
\text { Suhu Menggunakan } \\
\text { Mikrokontroller Arduino }\end{array}$ & $\begin{array}{c}\text { Kekurangan } \\
\text { Thermometer } \\
\text { Konvensional } \\
\text { (Air Raksa) }\end{array}$ \\
\hline 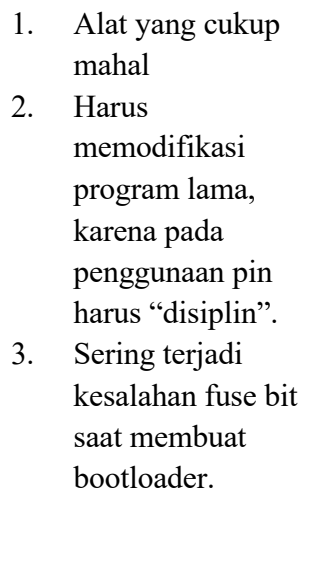 & $\begin{array}{ll}\text { 1. } & \text { Sukar diperoleh } \\
\text { sehingga air raksa } \\
\text { harganya cukup } \\
\text { mahal. } \\
\text { 2. } & \text { Air Raksa tidak } \\
\text { dapat digunakan } \\
\text { untuk mengukur } \\
\text { suhu yang sangat } \\
\text { rendah <-40o C } \\
\text { Air Raksa termasuk } \\
\text { zat beracun } \\
\text { sehingga berbahaya } \\
\text { apabila tabungnya } \\
\text { pecah. }\end{array}$ \\
\hline
\end{tabular}

\section{Skema Desain Proteus Dan Fritzing}

Skema desain dari proteus dan fritzing ditunjukkan pada Gambar 7 dan Gambar 8 berikut:

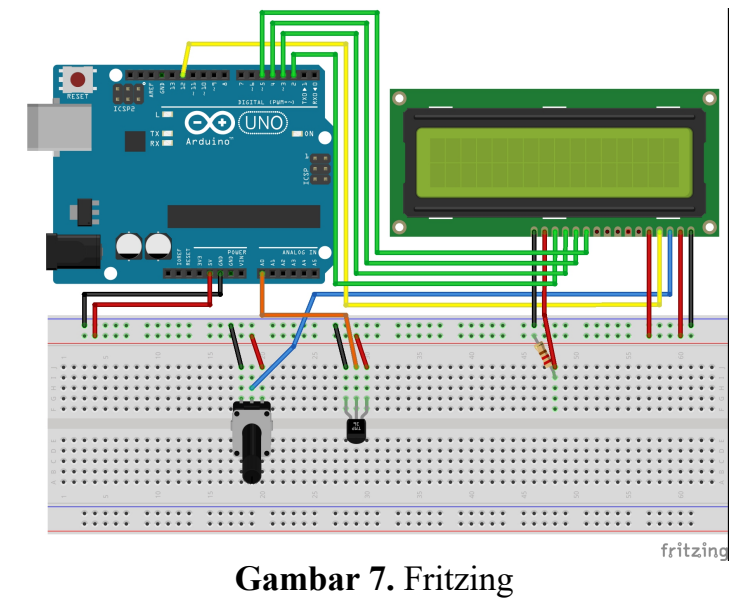


Keterangan rangkaian Gambar 7:

$\rightarrow$ Bisa Menggunakan Segala Jenis Arduino (UNO, NANO, MEGA, MINI, dll), karena penomoran pinnya sama. Tinggal cocokkan Saja nomor Pin-Pin nya.

$\rightarrow$ Pin VSS LCD $\Rightarrow>$ menuju ground

$\rightarrow$ Pin VCC LCD $\Rightarrow$ menuju power

$\rightarrow$ Pin VEE LCD $\Rightarrow$ menuju Potentiometer $=>$ power

$\rightarrow$ Pin Rs LCD $\Rightarrow>$ menuju Pin 12 Arduino

$\rightarrow$ Pin Rw LCD $=>$ Pin 12 Arduino

$\rightarrow$ Pin E LCD $\Rightarrow$ Pin 11 Arduino

$\rightarrow$ Pin $\mathrm{D} 4 \mathrm{LCD}=>$ Pin 5 Arduino

$\rightarrow$ Pin D5 LCD $=>$ Pin 4 Arduino

$\rightarrow$ Pin D6 LCD $\Rightarrow$ pin 3 Arduino

$\rightarrow$ Pin $\mathrm{D} 7 \mathrm{LCD}=>$ Pin 2 Arduino

$\rightarrow$ Sensor Suhu $\Rightarrow$ Analog Pin 0 Arduino $\Rightarrow$ Ground

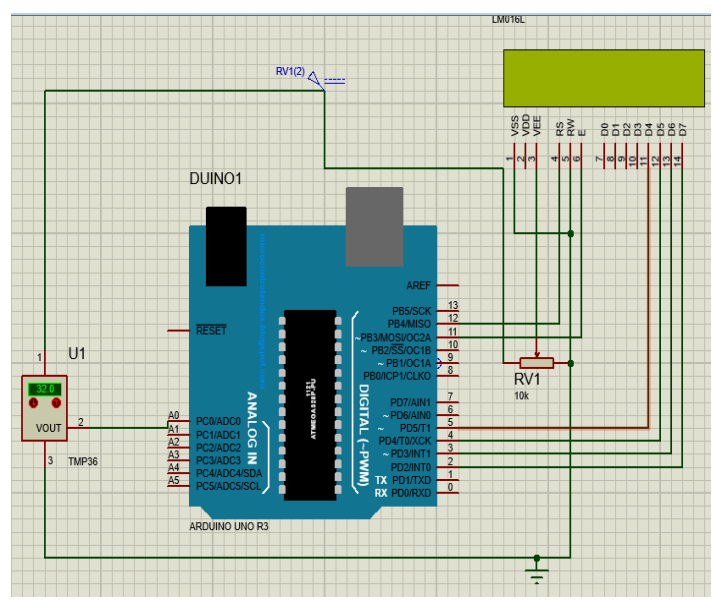

Gambar 8. Proteus

Pada Gambar 8 desain proteus memiliki beberapa perbedaan daripada alat sesungguhnya yang digunakan. Seperti pada desain sensor suhu memiliki angka yang bisa dinaikan dan diturunkan. Itu untuk mempermudah pengguna untuk mengetahui apakah sensornya bekerja dengan baik atau tidak. Dan nantinya angka yang berada pada sensor akan diproses melalui pin A0 Arduino Uno dan kemudian dimunculkan menggunakan LCD LM016L yang berada pada Gambar 3.

\section{KESIMPULAN}

Berdasarkan desain dan analisis perancangan ini, dapat disimpulkan bahwa alat yang sebelumnya digunakan masih belum efektif. Sehingga ketika alat mengalami kerusakan akan mengganti seluruh alat yang ada dan menyebabkan dana membengkak.
Perancangan alat yang lebih baik diperlukan untuk menghemat biaya dan mempermudah untuk dikembangkan kembali.

Alat pengukur suhu berbasis arduino ini memberikan kemudahan dalam memonitor suhu yang ada dan mempermudah pengembangan yang akan dilakukan nantinya. Dan juga proses pengukuran suhu yang lebih akurat dan cepat dapat langsung ditampilkan.

\section{DAFTAR PUSTAKA}

Arduino, 2019. Overview of Arduino Uno, http://www.arduino.cc/en/Main/arduinoBoardU no, diakses pada 8 November 2019.

Budioko, T. (2016). Sistem monitoring suhu jarak jauh berbasis internet of things menggunakan protokol MQTT. Prosiding Seminar Riset Teknologi Informasi (SRITI), pp. 353-358.

Malvino, A. P. (2000). Prinsip-prinsip Elektronika, Jilid 1, Edisi Ketiga, Jakarta: Penerbit Erlangga.

Marpaung, N. L., \& Ervianto, E. (2012). Data logger sensor suhu berbasis mikrokontroler atmega 8535 dengan PC sebagai tampilan. Jurnal Ilmiah Elite Elektro, 3 (1), 37-42.

Medri, Z. Z. (2018). Pendeteksi Suhu pada Perangkat Server Komputer Menggunakan Sensor DS18B20 dengan Spider Web View Berbasis Android. Skripsi. Medan: Universitas Sumatera Utara.

Prihatmoko, D. (2016). Perancangan dan implementasi pengontrol suhu ruangan berbasis mikrokontroller arduino uno. Simetris: Jurnal Teknik Mesin, Elektro dan Ilmu Komputer, 7 (1), 117-122.

Setiawan, I. (2009). Buku Ajar Sensor dan Transduser.

Setiawan, S. (2006). Mudah dan Menyenangkan Belajar Mikrokontroler. Yogyakarta: Andi Offset.

Sintia, W., Hamdani, D. \& Risdianto, E. (2018). Rancang bangun sistem monitoring kelembaban tanah dan suhu udara berbasis GSM SIM900A dan Arduino Uno. Jurnal Kumparan Fisika, 1 (2), 60-65. 
Suryadi, L., Darmanto, T., \& Yulius, A. A. P. (2016).

Perancangan sistem kontrol kipas angina otomatis menggunakan sensor suhu LM35 berbasis mikrokontroler ATMega16. Jurnal InTekSis, 2 (2), 78-82.

Wijaya, R. A., Lestari, S. W., \& Mardiono (2018).

Rancang bangun alat monitoring suhu dan kelembaban pada alat baby incubator berbasis internet of things. Jurnal Teknologi, 6 (1), 5270 .

www.datasheetcatalog.com, Datasheet IC TMP36, diunduh Oktober 2019. 